\title{
„Twórzmy relacje, a nie dzieci”. Wspólne życie na zniszczonej planecie w chthulucenie Donny Haraway
}

Tytuł: Staying with the Trouble:

Making Kin in the Chthulucene

Autorka: Donna J. Haraway

Wydawnictwo: Duke University Press Books

Rok wydania: 2016

Liczba stron: 312

\author{
Aleksandra Derra \\ Instytut Filozofii \\ Uniwersytet Mikołaja Kopernika \\ aldewicz@umk.pl \\ Przyjęto: 23 luty; zaakceptowano: 27 luty.
}

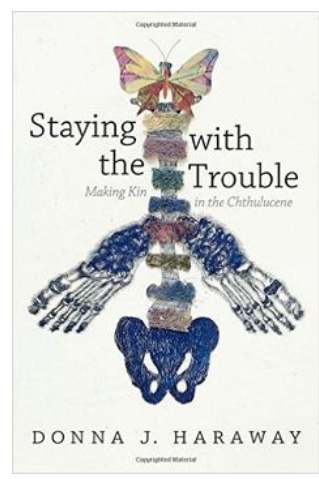

\begin{abstract}
Abstrakt
Celem artykułu jest omówienie podstawowych założeń, tez oraz rozstrzygnięć książki Donny Haraway Staying with the Trouble: Making Kin in the Chthulucene. Autorka sytuuje rozważania amerykańskiej filozofki i biolożki na tle jej wcześniejszych książek i propozycji konceptualnych. Analizuje jej propozycję posługiwania się kategoriami chthulucenu zamiast antropocenu, systemu sympojetycznego zamiast autopojetycznego, przedstawia jej apel o tworzenie nowych form pokrewieństwa i rozbudowanej odpowiedzialności za siebie nawzajem.
\end{abstract}

Słowa kluczowe: chthulucen; antropocen; system sympojetyczny; Donna Haraway; nowe formy pokrewieństwa; odpowiedzialność.

Przyzwyczaiłam się do określonego rodzaju doświadczeń związanych z czytaniem tekstów Donny Haraway. Po pierwsze jej książki poruszały mnie, fascynowały, denerwowały lub niepokoiły swoim niesztampowym językiem. Zaskakiwały mnie śmiałym i niespotykanym dotąd połączeniem literackości i kompetencji, zarówno w biologii, jak i w filozofii, zwłaszcza, że jestem/byłam 
przefiltrowana przez socjalizację w (umiarkowanym) scjentyzmie i przywiązaniu do programowej, a przynajmniej proklamowanej, a-metaforyczności dyskursu filozofii. Po drugie jej pomysły filozoficzne, bogata argumentacja, przykłady z historii nauki i współczesnej technonauki zmieniały nie tylko mój sposób myślenia, ale niekiedy boleśnie zmuszały do zweryfikowania poglądu na temat dopuszczalności metod czy zasadności priorytetów badawczych w naukach humanistycznych, społecznych, ale także biologicznych. Wreszcie jej niesłychana wrażliwość na obecność uprzedzeń w nauce (ze względu na płeć, rasę, wiek, pochodzenie etniczne, położenie geograficzne etc.) i wyczulenie na uwikłanie nauki w system powiązań ekonomicznych i militarnych wielokrotnie wymagały zastanowienia się, jak sama powinnam myśleć o dziedzinach, którymi interesuję się naukowo i jak uprawiać swoją własną.

Wskazując na obszary badawcze, w których jej idee naukowe okazały się nie tylko niezwykle wpływowe dla prowadzonych dyskusji, ale także przełomowe dla rozwoju konkretnej subdyscypliny, nie sposób nie wymienić antropologii posługującej się pojęciem cyborga, ekofeminizmu, postfeminizmu, posthumanizmu, feministycznych studiów nad nauką i technologią czy badań nad zwierzętami. Wymieniając najbardziej znane i przełomowe jej teksty, wypadałoby wspomnieć o takich jak Manifest cyborgów: nauka, technologia i feminizm socjalistyczny lat osiemdziesiatych (1985, wyd. pol. 2003), Simians, Cyborgs and Women: the Reinvention of Nature (1991), Modest_Witness@Second_Millennium.FemaleMan (﹎_Meets_OncoMouseTM. Feminism and Technoscience (1997), The Companion Species Manifesto. Dogs, People, and Significant Otherness (2003), When the Species Meet (2008). Z punktu widzenia ksztaltowania się moich własnych zainteresowań badawczych wymieniłabym jako niezwykle istotne dwie nieco mniej znane książki Haraway. Wersję książkową jej rozprawy doktorskiej Crystal, Fabrics and Fields. Metaphors of Organicism in Twentieth Century Developmental Biology opublikowaną w 1976 roku oraz Primate Visions. Gender, Race and Nature in the World of Modern Science z 1989 roku. W obu w centrum zainteresowań jest język, za pomocą którego formułowane są teorie naukowe; wpływ, jaki mają określone metafory na ukuwanie przyjmowanych $\mathrm{w}$ nich pojęć, kształtowanie badań w danej dziedzinie, na modelowanie priorytetów badawczych.

Haraway na przykładzie historii biologii rozwojowej oraz prymatologii pokazuje złożony proces konstruowania specjalistycznego języka tych nauk, który nie odbywa się poza kontekstem miejsca i światopoglądu czasu, w którym powstaje. Dokonuje się on pod presją obowiązujących wymogów naukowości i rygorów metodologicznych, możliwości technologicznych danego momentu historycznego, ale także pod wpływem oczekiwań społecznych czy przekonań, które w danym momencie stają się ważnym elementem opisywanego procesu. Już w tych książkach przedstawi Haraway tak charakterystyczny dla siebie pogląd, że teorie formułowane w nauce nie mają charakteru obiektywnego, jeśli obiektywność rozumieć jako bezstronność, neutralność, niezależność od 
narzędzi i technologii, całkowite zdystansowanie od wartości i światopoglądu, ogląd z boskiego punktu widzenia. Wiedza jest według niej zawsze usytuowana (Haraway, 2014), formułowana $\mathrm{z}$ określonego miejsca, w danym czasie, w imię określonych wartości i interesów. Jej wytwory i skutki ich działań poza laboratorium mogą mieć charakter zarówno pozytywny, jak i negatywny. Wydaje się, że dzisiaj nie sposób nie dostrzegać tych drugich, zwłaszcza, gdy spojrzymy na zgubne połączenie zmian cywilizacyjnych i postępu naukowego z hiperindywidualizmem, konsumpcjonizmem i logiką wolnego rynku. Recenzowana książka Staying with the Trouble: Making Kin in the Chthulucene w dużej mierze traktuje o tym, co złe, o naszych niespokojnych czasach antropocenu pełnych trudności, napięć ekonomicznych i politycznych, realnej perspektywy katastrofy ekologicznej. Autorka zastanawia się nad nowymi sposobami myślenia o świecie przyrody, a tym samym nad przekształceniem języka i metodologii biologii, przede wszystkim pisze jednak o niezwykle pilnej potrzebie odpowiedzialności i wspólnotowości, o konieczności stwarzania nowych form pokrewieństwa, by ocalić siebie i świat.

Niezbyt obszerna (170 stron tekstu głównego) książka składa się ze wstępu, ośmiu rozdziałów, bibliografii i indeksu. Historia wydań czy pierwodruków rozdziałów, z których składa się książka może rozczarowywać czytelniczkę czy czytelnika, którzy spodziewali się zupełnie nowej, spójnej całości. Jedynie ostatni ósmy rozdział został napisany specjalnie na jej potrzeby i stanowi materiał wcześniej nieopublikowany, pozostałe ukazały się wcześniej w latach 2012-2015 w rozmaitych czasopismach czy pracach zbiorowych. Stanowią one raczej osobne, luźno powiązane ze sobą opowieści, w których powracają podobne wątki, opowiedziane za każdym razem z nieco innej perspektywy. Siłą rzeczy pisane na inne potrzeby części książki są różnej długości i mają odmienną strukturę: w niektórych Autorka bardziej skupia się na rozstrzygnięciach pojęciowych, pozostałe to raczej studia przypadków, w których całą złożoność $\mathrm{i}$ wielowymiarowość tematyki związanej $\mathrm{z}$ antropocenem widać najwyraźniej. Ostatni rozdział zatytułowany „The Camille Stories” porusza nie tylko niezwykle interesującą problematykę zagrożeń demograficznych i ekologicznych, skutkujących kryzysami ekonomicznymi i społecznymi, ale został także skonstruowany na sposób literacki, zaskakujący i urzekający. Po kolei jednak.

Jaki cel stawia sobie Haraway w recenzowanej książce? Warto przyjrzeć się samemu tytułowi. Najważniejsze, co wyjaśnia we wstępie, to stawić czoła trudnym czasom, w jakim przyszło nam żyć (Haraway, 2016, s. 1). Są one trudne nie tylko $\mathrm{w}$ tym sensie, że spiętrzyły się $\mathrm{w}$ nich rozmaite problemy, ale także dlatego, że niezrozumiałe, wieloznaczne, pogmatwane, trudne do uchwycenia myślą. Stąd słowo „trouble”, pochodzące od francuskiego czasownika „troubler”, który znaczy „mieszać”, „przeszkadzać”, „zmętniać”. Chodzi o to, by nie tylko spekulować nad tym, co się stanie w przyszłości, lecz również nie odkładać spraw na później, nie zaprzeczać, że nic się nie stało (denializm) i nie 
pokładać bezkrytycznie post-oświeceniowych nadziei w tym, że technonauka wszystko w przyszłości naprawi (fiksacja na punkcie technologii) (Haraway, 2016, s. 3). Symbolicznie oddaje to kolejne użyte w tytule słowo „Chthulucene”, pochodzące od greckich słów „khthôn” oraz „kainos”. „Kainos” to określenie na to, co nowe, ożywcze, to, co ma się zacząć, „khthôn” zaś oznacza „ziemię”. Haraway wyjaśnia, że w połączeniu oznaczają one „[...] rodzaj czasu i miejsca, w którym mamy nauczyć się radzić sobie z życiem i umieraniem w odpowiedzialny sposób na zniszczonej planecie” (Haraway, 2016, s. 2). Pojęcie odpowiedzialności, które przewija się wielokrotnie na kartach książki oddaje Haraway neologizmem, w swoisty dla siebie sposób. Angielskie słowo „responsibility” zapisuje jako „response-ability”, co można tłumaczyć jako „zdolność do udzielenia odpowiedzi”, jako „odpowiadanie”, „zdolność do reagowania”. Kolejny cel to osłabić retorykę związaną z pojęciami antropocen (który raz jeszcze stawia na świeczniku człowieka jako najważniejszy i wyróżniony sposób istnienia na Ziemi) i kapitalocen (które z kolei naturalizuje procesy ekonomiczne, opisując je jako na tyle wszechogarniające, systemowe, zaawansowane, że nie da się ich zatrzymać). Haraway namawia do myślenia o wytwarzaniu powiązań z innymi niż ludzkie istnieniami („,making kin”) i zgodnego z tym działania na rzecz heterogenicznej wspólnoty. Jak pisze, potrzebujemy siebie nawzajem do współpracy, której nie potrafimy sobie jeszcze wyobrazić. Albo będziemy stawać się kimś innym, niż jesteśmy dzisiaj w kombinacji z innymi istnieniami na Ziemi, albo w ogóle nie staniemy się nikim (Haraway, 2016, s. 4). Biorąc pod uwagę wielkie szóste wymieranie gatunków, realne przeludnienie świata (przewiduje się, że w 2100 roku będzie 11 miliardów ludzi), gigantyczne dysproporcje w skutkach, jakie powyższe procesy mają dla biednych i dla bogatych oraz śmiercionośne zanieczyszczenie i zaśmiecenie środowiska, po prostu zginiemy.

Haraway jako filozofka używa figur retorycznych, z których najważniejszą i, jak sama przyznaje, wszechogarniającą jest „figura SF”, którą opisuje za pomocą kilku wyrażeń rozpoczynających się literami s i f. Wymienia „science fiction”, „speculative fabulation” (tworzenie spekulatywnych opowieści), „string figures”1 (figury, postaci ze sznurków), „speculative feminism” (feminizm spekulatywny), „science fact” (fakt nauki). Ta figura, dość tajemnicza, choć być może filozoficznie i językowo interesująca, rzeczywiście ma znaczenie raczej dla retoryki tekstu, przywoływana jest do czasu do czasu, by pokazać, że nauka potrzebuje opowieści, a te z kolei potrzebują feminizmu. Jak poetycko pisze Haraway w niezwykłej, nie do końca przetłumaczalnej grze słów: „It matters

\footnotetext{
${ }^{1}$ Hasło w Wikipedii podaje: „Figura stworzona ze sznurka to wzór, który powstaje przez manipulowanie sznurkiem przy użyciu palców lub czasami między palcami wielu osób. Figury mogą składać się z pojedynczych lub wielu obrazów, ich tworzenie może przybrać charakter gry lub stanowić część opowieści o różnych figurach tworzonych w określonej sekwencji. Popularną formą gry w sznurki jest „,cats’ cradle” (kocia kołyska), ale wiele figur ze sznurków jest znanych w wielu miejscach pod różnymi nazwami”. Por. https://en.wikipedia.org/wiki/String_figure
} 
what matters we use to think other matters with; it matters what stories we tell to tell other stories with; it matters what knots knot knots; what thoughts think thoughts, what description describe descriptions, what ties tie ties" (Haraway, 2016, s. 12). Figura SF nie pełni raczej roli strukturyzującej czy rusztowania, na którym opierają się rozważania $\mathrm{w}$ poszczególnych rozdziałach. Służy $\mathrm{w}$ większym stopniu wzmocnieniu przekazu, podobnie jak ponad trzydzieści ilustracji wzbogacających książkę i jej przepiękna okładka.

Jak wskazywałam wcześniej, rozdziały w książce nie są ze sobą ściśle powiązane. $\mathrm{W}$ związku $\mathrm{z}$ tym przyjrzę się $\mathrm{z}$ różnym entuzjazmem i ze zróżnicowaną przenikliwością - $\mathrm{w}$ zależności od siły przekazu, z jaką na mnie wpłynęły - każdemu z nich po kolei.

Tytułem pierwszego rozdziału „Playing String Figures with Companion Species” Haraway odwołuje się do swoich wcześniejszych prac, w których posługiwała się kategorią „gry sznurkami w kocią kołyskę" (Haraway, 1994) oraz pojęciem gatunków stowarzyszonych (Haraway, 2003), by uchwycić współczesną podmiotowość. Wprowadza pojęcie „Terrapolis” (Haraway, 2016, s. 11), odnosząc je do specyfiki świata współczesnego, które zaludniają gatunki stowarzyszone nie w formie podmiotów post-ludzkich, ale w formie kompostu, mieszaniny rozmaitych istnień, wchodzących ze sobą w złożone zależności. Haraway odmawia uznania ludzkiej wyjątkowości, nie chce jednak myśleć kategoriami posthumanistycznymi (Haraway, 2016, s. 13). Podobnie jak Isabelle Stengers uważa, że radzenie sobie z trudnościami współczesnego świata musi odbywać się za pomocą narzędzi kosmopolitycznych, z udziałem wszystkich tych, którzy będą ponosili konsekwencje podejmowanych w nim działań; musi mieć charakter wielogatunkowej odpowiedzi (Stengers, 2010). Metafora gry sznurkami ma podkreślić, że nie da się tu oddzielić myślenia od działania; że gra jest zarówno praktyką myślenia, jak i działania (Haraway, 2016, s. 14). Przewodnikiem rozważań w tym rozdziale są gołębie, historia ich zadomowienia się $\mathrm{w}$ miastach, sposoby ich traktowania, role, jakie spełniają, relacje, $w$ jakie wchodzą z ludźmi i innymi mieszkańcami świata. Autorka podkreśla, że cały szereg pozytywnych $\mathrm{w}$ skutkach dla ludzi działań odbywa się za pomocą i z udziałem gołębi czy innych stworzeń, które najczęściej pozostają niewidzialne. Co więcej, dzięki wzajemnej współpracy gołębi i ludzi, zdolności zarówno ludzi, jak i gołębi zostają powiększone, co umożliwia zupełnie nowe działania. Jako przykład podaje projekt Pigeon-Blog, w którym mamy pracujące gołębie, artystów, inżynierów, hodowców i miłośników gołębi zaangażowanych w monitorowanie zanieczyszczenia powietrza w południowej Kalifornii (Haraway, 2016, s. 21). Stosownie wyposażone w odpowiednią maszynerię, współpracujące ze swoimi ludzkimi przyjaciółmi ptaki zbierają dane o zanieczyszczeniu w czasie rzeczywistym, w niedostępnych miejscach, które przekazywane są odpowiednim systemom komunikacyjnym w Internecie. Opisywany projekt nie ma charakteru naukowego, z tego zresztą powodu został zakwestionowany przez PETA (People for the Ethical Treatment of Animals) jako 
niedopuszczalne działania z użyciem zwierząt, bo niesłużące uświęconym celom naukowym (Haraway, 2016, s. 23). Inicjatywa ta korzystała z wiedzy i doświadczeń miłośników gołębi oraz zwykłych ludzi, wchodzących w relacje z gołębiami miejskimi, by poszerzyć rozumienie wspólnoty, przejść od myślenia o gołębiach jako „szczurach ze skrzydłami” do traktowania ich jako zwierząt wchodzących w relacje społeczne (Haraway, 2016, s. 24). Upodmiotowione gołębie doczekały się wybudowania zaprojektowanych dla nich przez artystów schronień, w których mogły zamieszkać w zgodzie ze swoimi potrzebami ekologicznymi i bez niszczenia zasobów miasta (np. Capsule w Lille, loft w Batman Park w Melbourne). Haraway podkreśla, że podawanie szczegółów w przedstawianych historiach ma ogromne znaczenie. Wszyscy jesteśmy współodpowiedzialni za warunki, w jakich żyją różno-gatunkowe stworzenia, nie jesteśmy jednak odpowiedzialni w ten sam sposób, wszystko zależy od różnic ekologicznych, ekonomicznych, związanych z przynależnością do gatunku i sposobu życia, żeby to uwzględnić, trzeba przytoczyć szczegóły (Haraway, 2016, s. 29).

W rozdziale drugim „Tentacular thinking” („Myślenie za pomocą macek”) w podtytule zostają wymienione kategorie antropocenu, kapitalocenu i chthulocenu. Otwiera go niezmiernie istotne dla całej książki pytanie o to, co dzieje się, kiedy nie da się już ani myśleć, ani działać, kierując się zarówno w teorii, jak i w praktykach ludzką wyjątkowością i indywidualizmem (Haraway, 2016, s. 30). Według Haraway, biorąc pod uwagę niewiarygodne spustoszenie świata przyrody, jakiego dokonał człowiek i niepewność oraz nieprzewidywalność konsekwencji tego spustoszenia, nie można okresu przejściowego, w jakim się na Ziemi znajdujemy nazywać antropocenem. Stąd propozycja, by używać określenia „chthulocen” z odwołaniem do figury pająka „Pimoa cthulhu”, odniesieniem do języka Goshute mieszkańców Utah (Haraway, 2016, s. 31) oraz mieszkającego na dnie oceanu bóstwa czy ośmiornicy o wielu mackach (swoistego pająka mórz). Żeby spróbować realizować potencjał nowych trybów myślenia o współczesnej podmiotowości Haraway wprowadza pojęcie humusu i sympojezy. Humus - ziemska materii organiczna - określa heterogeniczną rodzinę stworzeń, które zamieszkują Ziemię od grzybów poprzez bakterie, rośliny i zwierzęta. Sympojezę (w odróżnieniu od autopojezy) pożycza Autorka od M. Beth Dempster i jej pracy magisterskiej z 1998 roku z zakresu studiów środowiskowych. Nazywa ona wytwarzane w sposób zbiorowy systemy, w których przepływ informacji i kontrola są rozproszone w różnych jego elementach, a ich granice nie są ściśle wyznaczone, system jest bowiem ewolucyjnie zmienny (Haraway, 2016, s. 33). Zarówno współczesna filozofia, jak i nauki biologiczne wydają się już nie posługiwać pojęciami zbudowanymi na ściśle od siebie odgraniczonych jednostkach, zindywidualizowanych bytach jak geny, organizmy czy środowiska (Haraway, 2016, ss. 30, 33). Nie tylko bowiem nie da się uprawiać nauki podobnie jak dotychczas, ale nie da się dalej żyć tak samo jak dotąd na zrujnowanej planecie na zgliszczach kapitalizmu. Haraway 
przywołuje w tym rozdziale rozważania na temat zła Hannah Arendt, sztuki życia Anny Tsing, etyki Thoma van Doorena. umiejętności opowiadania historii Ursuli Le Guin, postulat opowiadania „opowieści Gai” Brunona Latoura. Powtarzając postulat Stengers, zgodnie z którym nie chodzi o to, by stawić Gai czoła, Haraway nawołuje do potraktowania Gai/Ziemi jako złożonego zjawiska systemowego, które buduje naszą planetę (Haraway, 2016, s. 43). To nawołanie nie jest kolejną teoretyczną odezwą i próbą zbudowania oryginalnego systemu pojęć. Nie można nie działać, trzeba zmienić myślenie, by działać natychmiast. Bred Werner na konferencji w San Francisco w 2012 roku przekonywał, że $\mathrm{z}$ naukowego punktu widzenia jedyne, co sensownego można w obecnej sytuacji zrobić, to rewolta, rewolucja, działanie zbiorowe. Wedle niego globalny kapitalizm doprowadził do tak raptownego wyniszczenia zasobów, że nie jesteśmy w stanie przewidzieć, jak zachowają się ludzko-ziemskie systemy (Haraway, 2016, s. 47).

Haraway streszcza w tym rozdziale, co dokładnie nie podoba się jej w antropocenie jako pojęciu, narzędziu, epoce czy opowieści. Opowieść o nim traktuje o śmierci i beznadziei, w tej sytuacji nie da się nią nakłonić do działania. Sam gatunek ludzki nie tworzy historii, co antropocen chciałby zasugerować. Nie tworzą jej także ludzie $\mathrm{z}$ dodatkiem narzędzi i innych stworzeń, opowieści o współczesnym świecie nie mogą być opowieściami tylko o tym. Antropocen w za dużym stopniu wspiera się na utylitarystycznym indywidualizmie oraz ewolucjonizmie nowoczesnej syntezy. Wreszcie mamy tu aspekt ekonomiczny - pojęcia antropocenu mogą i potrafią używać intelektualiści z wyższych klas i dostatnich krajów (Haraway, 2016, s. 49). Kryją się w nim demony nowoczesności, determinizmu, modernizacji, podziału natura/społeczeństwo, postępu i teleologii. Wedle Haraway potrzebujemy opowieści, zgodnie z którą inny świat nie tylko jest pilnie potrzebny, ale także możliwy. Chthulucen jest propozycją alternatywnej opowieści, w której ludzie nie są najważniejszymi bohaterami; tworzą ją praktyki istnienia wielu stworzeń, bez wyróżniania głównego bohatera, w trudnych czasach, w których świat się jeszcze nie skończył, a niebo nie spadło jeszcze wszystkim na głowę (Haraway, 2016, s. 55). Nie jest to opowieść globalna, wielka i wszechogarniająca, ale opowiastki bez nuty apokaliptycznej paniki i samozadowolenia sytego króla.

W kolejnych rozdziałach Haraway przedstawia szczegóły związane z kategorią sympojezy i tworzenia nowych form wspólnotowości oraz pokrewieństwa $\mathrm{w}$ chtulucenie. Krótkie rozdziały czwarty ( 5 stron), szósty (9 stron) oraz siódmy (8 stron) nie zawierają rozbudowanej argumentacji, luźno odwołują się do prac filozoficznych, opracowań naukowych, tekstów science fiction oraz praktyk codziennych, znajdziemy w nich typową dla Autorki rozbudowaną metaforykę.

W rozdziale czwartym Autorka przedstawia raz jeszcze, jak rozumie chtulucen, zasięg zmian, jaki przynosi, sposoby reagowania na nie w nauce i w praktykach polityczno-społecznych. Zastanawiając się nad tym, jakim przykuwającym 
uwagę sloganem można by go zilustrować, wybiera „Make Kin, Not Babies” („Twórzmy relacje, a nie dzieci”) (Haraway, 2016, s. 102). Warto przywołać tutaj jej ciekawy pogląd na problem przeludnienia naszej planety. Przypomina ona, że to myśl i działalność feministyczna nieustannie domagały się, by kobiety miały wybór w sprawie dzieci; by sensu ich istnienia nie sprowadzać do ich posiadania; by mogły wybrać nieposiadanie dzieci (Haraway, 2016, s. 6). Potrzebując rodziny, bliskich, więzi, mamy skupić się na poszerzaniu naszego myślenia o tym, kim mogliby być nasi najbliżsi. Krewny, zgodnie wyjściowym, pierwotnym znaczeniem angielskiego słowa „relative” oznaczał „powiązania logiczne", a stał się określeniem na członka rodziny dopiero w XVII wieku (Haraway, 2016, s. 103). Nasi bliscy to wszystkie te ziemskie istoty, z którymi jesteśmy w danym miejscu i czasie powiązani, wszystkie te, o które należy się zatroszczyć, także dla naszego dobra.

W rozdziale szóstym Haraway bada możliwości znaczeniowe tytułowego sloganu książki „Stay with the Trouble”, który można by rozumieć jako nawołanie do nieuciekania przed trudnościami, do zmierzenia się z nimi, w pewnym sensie zaakceptowania tego, z czym mamy w świecie dzisiaj do czynienia i podjęcia próby poradzenia sobie z tym. Haraway na razie podpowiada zmianę sposobu myślenia, polegającą na dostrzeżeniu roli roślin, bakterii, grzybów, z którymi się komunikujemy i z którymi wzajemnie się potrzebujemy (Haraway, 2016, s. 122). Pojawiają się tutaj kategorie symbiogenezy oraz sympojezy (do tego pojęcia jeszcze powrócę) jako niezbędne do tego, by opisać współczesną przyrodę. Słowo „symbiogenza” można rozbić na składowe, które z języka greckiego znaczą odpowiednio: „sún”, czyli „razem”, „biosis” - „życie”, a „genesis” - „pochodzenie”. Podkreśla się tutaj, że gatunki powstały dzięki integracji i symbiozie, co dla Haraway oznacza odejście od fantazji na temat niezależnych, samo-stwarzających się i samowystarczalnych systemów autopojetycznych na rzecz systemów, które współtworzą swoją tożsamość z innymi, stając się współodpowiedzialne za siebie nawzajem. Nie oznacza to tylko tego, co dobre, czy idylli, lecz również komunikację, pochodzenie z tej samej materii, troskę i wzajemne „matkowanie”. Haraway nie po raz pierwszy oddaje to metaforą w postaci sekwencji słów: „mutter, matter, mother” („mamrotanie, materia, matka") (Haraway, 2016, s. 125), pojawiła się ona choćby w jej tekście Wiedza usytuowana.

W rozdziale siódmym Haraway przedstawia niezwykle interesujący sposób, w jaki Vinciane Despret, obserwując naukowców próbuje opisać charakter badań terenowych biologów. Odwołuje się do cnoty grzeczności, by oddać specyfikę swoistych odwiedzin, jakie składają naukowcy, obserwujący zwierzęta (Haraway, 2016, s. 127). Twierdzi ona, że to, co robią naukowcy, oddziałuje na sposób, w jaki zwierzęta reagują na ich działania. Jako przykład podaje badania Amotza Zahaviego nad dżunglotymalami arabskimi (ptakami z rodziny pekińczyków), który swoim postępowaniem celowo przeprowadzał eksperymenty z ptakami, które obserwował, a nie na ptakach (Haraway, 2016, 
s. 128). Można powiedzieć, że eksperymenty przeprowadzali razem, skutecznie się ze sobą komunikując. Pokazując istotną rolę komunikowania się z innymi stworzeniami, Haraway podkreśla, że aby zwierzęta nas karmiły, my musimy „żywić” je w codziennych praktykach, które polegają na współ-pracy, konwersacji i poświęcaniu sobie wzajemnie uwagi (Haraway, 2016, s. 129). Nie ma na nie miejsca we współczesnym świecie hodowli przemysłowej, odpersonalizowanej produkcji zwierząt laboratoryjnych czy eksploatacji środowiska naturalnego bez względu na los jego wielogatunkowych mieszkańców.

Znacznie bardziej rozbudowane rozdziały trzeci i piaty wymagają poświęcenia nieco więcej czytelniczej uwagi. W rozdziale trzecim zatytułowanym „Sympoiesis” Haraway raz jeszcze odwołuje się do znaczenia tego pochodzącego z języka greckiego słowa: „sún” oznacza „razem”, „poíēsis” zaś „tworzenie”, mamy tutaj zatem „tworzenie czegoś razem”. Nic nie tworzy się samo z siebie, nikt i nic nie jest samowystarczalny. Ontologiczna propozycja Haraway jest taka, by porzucić kategorie odrębnych jednostek oraz istnień (gatunków, rodzajów etc.) na rzecz kategorii holobiontów i symbiontów² (Haraway, 2016, s. 60). Raz jeszcze przywołane zostają tu tezy $M$. Beth Dempster $z$ nużącym powtórzeniem tych samych cytatów, które już wcześniej znajdziemy w książce. Ponownie mowa tu o roli nowoczesnej syntezy w kształtowaniu pojęć i tradycji badawczej w biologii; o odchodzeniu nauk o życiu od skupiania się na odrębnych organizmach w stronę relacyjności i powiązań; o potrzebie badania międzygatunkowości, tego, co pozwala się rozwijać, utrzymywać w całości i komunikować się tym wielowarstwowym tkankom, jakimi są zwierzęta (Haraway, 2016, s. 65). Ogromna w tym zasługa technologii DNA i genomiki, które pozwalają pokazać symbiotyczną różnorodność świata ożywionego (Haraway, 2016, ss. 66-67). Scott Gilbert, Jan Sapp i Alfred Tauber (Gilbert, Sapp, Tauber, 2012) napisali artykuł poświęcony sympojezie zatytułowany A Symbiotic View of Life: We Have Never Been Individuals (Symbiotyczne ujęcie życia: nigdy nie byliśmy indywidualistami), którego druga część parafrazuje tytuł książki Latoura Nigdy nie byliśmy nowocześni (Latour 2011). Z kolei Carla Hustak i Natasha Myers, przywoływane przez Autorkę, przekonywały, że „przedstawianie przyrody jako gry o sumie zerowej między rywalizującymi między sobą indywiduami to karykatura chemicznego, biologicznego, materialno-semiotycznego świata" (Hustak, Meyers 2012). W tym rozdziale Haraway zwraca uwagę na to, że zmiana słownika naukowego, aktywizm, nie wystarczą, żeby poradzić sobie z problemami współczesnego świata, potrzebujemy także działań oraz opowieści społecznych i artystycznych. Innymi słowy biologia, sztuka i polityka wzajemnie siebie potrzebują - choćby takich projektów jak Crochet Coral Reef3',

\footnotetext{
${ }^{2}$ Holobionty to złożenia różnych gatunków, które tworzą osobne ekologiczne jednostki, symbionty to organizmy, które żyją w symbiozie z organizmami innego gatunku.

${ }^{3}$ Odkrycie i rozpoznanie, że podnoszenie temperatury mórz sprawia, że wymierają ekosystemy raf koralowych, przyczyniło się do rozpowszechnienia pojęcia antropocenu.
} 
Ako Project z Madagaskaru, gra „Never Alone” czy działania związane z ratowaniem dziedzictwa ludów Hopi i Nawaho (Haraway, 2016, s. 71), które zostają przedstawione i zilustrowane $\mathrm{w}$ omawianym rozdziale.

Najbardziej poruszająca historia tej części książki to opowieść o ludzie Nawahów (Haraway, 2016, s. 89-97), która także ilustruje twierdzenie Haraway, że problem nie polega na tym, że na Ziemi zachodzą zmiany, ale na ich zasięgu i zakresie oraz rozlokowaniu na świecie (Haraway, 2016, s. 73). Najbiedniejszymi obywatelami Stanów Zjednoczonych są obecnie ludy Hopi i Diné zamieszkujące Kraj Nawahów. Opowieść o nich to opowieść o przemocy przemysłu węglowego, którego lobbyści usuwali za pomocą narzędzi politycznych (Kongresu USA) rdzenne ludy z miejsc, w których można było rozwijać przemył energetyczny, wysiedlając tysiące ludzi i dewastując środowisko naturalne. Te relokacje nie odbywały się jedynie setki lat temu w dawnych czasach barbarzyństwa, lecz w latach siedemdziesiątych i osiemdziesiątych XX wieku (Haraway, 2016, s. 75). W XIX wieku ludobójstwo odbywało się pośrednio. W 1863 roku decyzją Departamentu Wojny Stanów Zjednoczonych zmuszono rdzenne ludy do przemieszczenia się pieszo z Dineath do rezerwatu Bosque Redondo w Fort Sumner, w Nowym Meksyku, przez kolejne pięć lat więziono tam 9.500 Nawahów i 500 Apaczów Mescalero. Systematycznie i w sposób zaplanowany eksterminowano także hodowane przez Nawahów owce Churro, które były istotną częścią tożsamości Nawahów, ich kultury i porządku społecznego. Pozwalały im się utrzymać i kultywować tradycje tkania dywanów, co miało charakter religijny i symboliczny. Eksterminacja odbywała się siłą, za pomocą narzędzi Departamentu Wojny, Ministerstwa Rolnictwa i związanych z nim naukowców, ideologii Nowego Ładu, modernizacji i nowoczesnego rolnictwa. W latach trzydziestych XX wieku zabito niemal wszystkie owce i większość kóz, dzięki którym ludy te nie umierały z głodu (w sumie około miliona owiec i kóz, bez żadnego odszkodowania, w 1970 roku pozostało około 430 owiec Churro, rozproszonych po całym rezerwacie). Dzisiaj za pomocą działalności organizacji takich jak choćby Black Mesa Water Coalision (BMWC) próbuje się przywracać sprawiedliwość energetyczną, relacje ekonomiczne, które pozwalają upodmiotowić słabszych oraz walczyć na rzecz sprawiedliwości klimatycznej południowego zachodu Stanów Zjednoczonych, zwłaszcza regionu Black Mesa.

Rozdział piąty tytułem - „Awash in Urine. DES and Premarin in Multispecies Response-ability" - zapowiada przewijającą się w całej książce problematykę odpowiedzialności czy, używając języka Haraway, wypracowywania zdolności do odpowiadania. Znajdziemy w nim opowieść - a jakże! - o dwunastoletniej suce Autorki Cayenne, która zaczęła przyjmować (a raczej zaczęto jej podawać) syntetycznie wytwarzany na skalę przemysłową estrogen DES, by zapobiec problemom z nietrzymaniem moczu i chronić jej serce. Ten na pierwszy rzut oka prosty gest troski o dobrostan zwierzęcia i swój własny, wywołuje jednak w Autorce zaburzenia lękowe, przywołuje całą masę heterogenicznych 
związków, z jakimi mieliśmy i mamy tutaj do czynienia. Po pierwsze niepokój z gruntu feministyczny, bo niedobór estrogenu powodujący rozmaite niedostatki zdrowotne, ściśle związane $\mathrm{z}$ wygasaniem możliwości reprodukcji, odnosi się nie tylko do samic psów, ale także do kobiet. Tak jakby na starość utrata hormonu skutkowała utratą kobiecości, wymagała naprawy! Po drugie lęk o możliwe uczynienie krzywdy. Wystawianie płodu ludzkiego na działanie tego leku między 1940 a 1970 rokiem skutkowało możliwym gruczolakorakiem, spekulowano, że wywoływał on skurcze, poronienia i przedwczesne porody. Od lat dziewięćdziesiątych XX wieku w Stanach Zjednoczonych można go podawać jedynie zwierzętom i w rzadkich przypadkach ludziom. Inna strona tego samego medalu to (niewidoczna) zależność ludzi od zwierząt w przypadku stosowania leków. Autorka opisuje swoje własne doświadczenie przyjmowania leku Premarin w czasie menopauzy, który zawiera naturalne estrogeny pozyskiwane z moczu koni. Haraway ze smutkiem stwierdza, że jako feministyczna badaczka studiów nad nauką i technologią i długoletnia wielbicielka zwierząt, oblekając się w menopauzalne ja nie zdołała zauważyć losu kobył i ich źrebiąt „jednorazowego użytku”. Pyta: „Czy zapomniałam, nigdy nie wiedziałam, nie dociekałam - czy po prostu mnie to nie obchodziło?” (Haraway, 2016, s. 111). Jak podkreśla, relacje między ludźmi a zwierzętami, między nami a poza-ludzkimi krewnymi, nie są niewinne, a nasza za nie odpowiedzialność jest dużo większa i w dużej mierze nigdy się nie kończy (Haraway, 2016, s. 114). Żeby to jednak zauważyć, musimy znać szczegóły, dostrzec niewiarygodną złożoność powiązań, wtedy dopiero widać, gdzie nasze odpowiadanie powinno mieć miejsce. Dziś już wiemy, że „korporacje, gospodarstwa rolne, kliniki, laboratoria, domy, nauka, technologie, wielogatunkowe istnienia są ze sobą powiązane” w czasie, w różnej skali, materialnie... (Haraway, 2016, s. 115).

Wspomniałam już o tym, że ostatni, ósmy rozdział recenzowanej książki to jedyny jej fragment, który nie jest przedrukiem i ukazuje się w tej postaci po raz pierwszy. Zatytułowany jest „Historia Camille. Dzieci kompostu”, wzbogaca go dziewięć różnorodnych ilustracji i napisany został niezwykle literackim językiem. Haraway przyznaje, że powstał jako językowy wytwór wyobraźni na warsztacie pisania, w jakim Autorka wzięła udział latem 2013 roku w Cerisy. Zadaniem uczestników każdej z wydzielonych grup na warsztacie było pisarskie powołanie do istnienia dziecka i opisanie życia jego i jego potomków przez pięć ludzkich pokoleń. W grupie Haraway opowieść w jej pierwotnych, warsztatowych wersjach współtworzyli także filmowiec Fabrizio Terranova oraz filozofka i psycholożka Vinciane Despret. Celem tego literackiego eksperymentu było stworzenie fikcji, ale możliwej do wyobrażenia, bez przywiązywania wagi do tradycyjnych podziałów ontologicznych i dotychczasowych realnych sposobów życia na zniszczonej planecie. Camille, jak pisze Haraway, została wymyślona jako dziecko urodzone dla sympojezy, stwarzające swoją tożsamość z innymi, dzięki innym, działając z innymi, naj- 
przeróżniejszymi, różnorodnymi stworzeniami zamieszkującymi planetę (Haraway, 2016, s. 137). Te ćwiczenia wyobraźni miały swoje ograniczenia, nakładane przez dotychczasową wiedzę o zrujnowanym świecie, stąd w stwarzaniu światów Camille przyjęto kilka reguł (Haraway, 2016, ss. 138143). Żadna ze społeczności kompostu (kolejnych pokoleń opisywanych w tej historii istnień) nie może zaczać od zera i przenieść się do jakiegoś niezamieszkiwanego terenu. Nie może opuścić zniszczonej ziemi, ale musi próbować na niej żyć, tworząc nowe wspólnoty i naprawiając to, co się da. Ze względu na przeludnienie Ziemi, zachęca się do powoływania do życia innych niż ludzkie stworzenia, zachowuje wolność reprodukcyjną, przyjmuje się jednak, że pojawienie się każdego nowego życia to zmiana struktury całej wspólnoty, musi zatem ona być częścią tego procesu. Dlatego ludzkie dzieci przychodzą na świat jako symbionty ze stworzeniami z jakiegoś ginącego gatunku. Częścią edukacji jest nauka współ-życia z symbiontem i wszystkich istnień z nim związanych przez kolejne pięć ludzkich pokoleń. Nowa istota może wybrać płeć bądź nie wybrać jej wcale, może dowolnie przekształcać ciało, wzbogacać je o mikroorganizmy ze zwierzęcego świata, by poszerzać swoją percepcję tak, aby doświadczać świata podobnie jak symbiotycznie $\mathrm{z}$ nią związane zwierzęce stworzenia. Ta ingerencja dotyka jedynie ludzi, nie przeprowadza się ich na zwierzętach i roślinach, ale ze względu na zmiany w funkcjonowaniu ludzi, flora i fauna zmieniają się wraz z nimi .

Przedstawiana przez Haraway opowieść obejmuje historię życia pięciu Camilli, od pierwszej urodzonej w 2025 roku do piątej, która umiera w 2425 roku. Każda z nich rozpoczyna się od podania danych: „Urodzona w roku...”, „Liczba ludzi wynosi...”, „Umiera w roku...”, „Liczba ludzi wynosi ...”. Kiedy rodzi się pierwsza Camille ludzi na Ziemi jest osiem miliardów, kiedy umiera, jest ich już dziesięć miliardów. Kiedy umiera piąta Camille na Ziemi żyje trzy miliardy ludzi, z tego dwa miliardy to ludzko-zwierzęce symbionty, z powierzchni Ziemi znika ponad połowa gatunków żyjących na niej w 2015 roku. Miliony rodzajów różnych stworów tworzy symbionty z ludźmi, przy czym zwierzęce symbionty nie zostają zmienione za pomocą ludzkich genów. Ludzkie symbionty przejmują wiele $\mathrm{z}$ własności swoich zwierzęcych partnerów... W trakcie życia pięciu pokoleń Camille dzieją się niezwykłe rzeczy na Ziemi, nie da się tego powiedzieć, trzeba o tym przeczytać i sobie to wyobrazić. Haraway opisuje je spójnie i przekonująco jako biolożka, z wrażliwością metodologicznie wprawionej filozofki świadomej historii nauki i z literackim wdziękiem pisarki. Ze względu na ten liczący 33 strony rozdział, warto było przeczytać całą książkę!

\footnotetext{
${ }^{4}$ Haraway odwołuje się w tym miejscu do „EcoEvoDevo”, czyli do „ekologicznej, ewolucyjnej biologii rozwojowej”, w której symbioza i plastyczność w rozwoju są traktowane jako czynniki zmian ewolucyjnych.
} 
Książki Staying with the Trouble nie domyka osobne zakończenie. To nie koniec bowiem, ale początek. Zupełnie nieoptymistyczny, zasmucający raczej i pesymistyczny. Początek jednak, jak każdy, dający nadzieję na zmianę.

Nie da się zaprzeczyć, że książka Haraway porusza niezwykle aktualną problematykę nie tylko współczesnej humanistyki, ale także nauk biologicznych. Zadaje pytanie o to, jakich pojęć i teorii należałoby użyć, by opisać dzisiejszego człowieka; uchwycić jego hybrydyczność, uwikłanie w technologie, relacje ekonomiczne, zmiany środowiskowe, procesy demograficzne, kryzysy polityczne i społeczne. Czy to post-człowiek w przeludnionym ginącym świecie? Czy symbiont próbujący na nowo zbudować relacje z innymi? Część globalnego humusu? Autorka zajmuje się problemami konceptualnymi współczesnych nauk o życiu, ich próbach odejścia od słownika i teorii ufundowanych na zindywidualizowanych kategoriach i idei rywalizacji. Nie o słowa tu jednak wyłącznie chodzi, ale o to, by dały asumpt do działania, którego celem jest ratowanie świata. Czytelniczka i czytelnik po lekturze poczują się zagubieni: brakuje spójności, gotowych recept, argumentacji, którymi można by się posłużyć. Na razie tyle musi wystarczyć. Na razie mamy zastanowić się, jak tworzyć relacje zamiast dzieci. Jak poszerzać swoją rodzinę bez dalszego przeludniania świata. To wystarczająco trudny początek...

\section{Literatura}

Gilbert, S. F., Sapp, J., Tauber, A. (2012). A symbiotic view of life: We have never been individuals. The Quarterly Review of Biology, 87(4), 325-341.

Haraway, D. (1994). A game of cat's cradle: Science studies, feminist theory, cultural studies. Configurations, 1, 59-71.

Haraway, D. (2003). The companion species manifesto: Dogs, people, and significant otherness. Chicago, IL: Prickly Paradigm Press.

Haraway, D. (2014). Wiedza usytuowana: Problem z nauka w feminizmie a przywilej przyjęcia częściowej, niepetnej perspektywy. (A. Derra, tłum.), W E. Bińczyk; A. Derra (red.), Studia nad nauka i technologia: Wybór tekstów (ss. 103-133). Toruń: Wydawnictwo Naukowe UMK.

Haraway, D. (2016). Staying with the trouble: Making kin in the chthulucene. Durham, UK: Duke University Press.

Hustak, C., Myers, N. (2012). Involutionary momentum. Differences, 23(3), 74-118.

Latour, B. (2011). Nigdy nie byliśmy nowocześni. Studium z antropologii symetrycznej. (M. Gdula, tłum.). Warszawa: Oficyna Naukowa.

Stengers, I. (2010). Cosmopolitics I. (R. Bononno, tłum.). Mineapolis: University of Minnesota Press. 
„Make Kin, Not Babies”. Living Together on a Damaged Planet in the Chthulucene of Donna Haraway

\begin{abstract}
The aim of the article is to discuss the basic assumptions, theses and solutions of Donna Haraway's book "Staying with the Trouble: Making Kin in the Chthulucene". The author places the considerations of an American philosopher and biologist on the background of her earlier books and conceptual proposals. She analyses her suggestion of using the category of Chthulucene instead of Anthropocene, the category of sympoietic system instead of an autopoietic one, she presents her appeal for creating new forms of kinship and extensive response-ability for each other.
\end{abstract}

Keywords: Chthulucene; Anthropocene; sympoietic system; Donna Haraway; new kin; response-ability 